\title{
Netilmicin Sulfate
}

\author{
National Cancer Institute
}

\section{Source}

National Cancer Institute. Netilmicin Sulfate. NCI Thesaurus. Code C66237.

The sulfate salt form of netilimicin, a semisynthetic, water soluble aminoglycoside antibiotic. Netilmicin is derived from sisomicin, a naturally occurring aminoglycoside antibiotic produced by the fermentation of Micromonospora inyoensis. Netilmicin irreversibly binds to the $16 \mathrm{~S}$ rRNA and S12 protein of the bacterial $30 \mathrm{~S}$ ribosomal subunit. As a result, this agent interferes with the assembly of initiation complex between mRNA and the bacterial ribosome, thereby inhibiting the initiation of protein synthesis. In addition, netilmicin induces misreading of the mRNA template and causes translational frameshift, thereby results in premature termination. This eventually leads to bacterial cell death. 